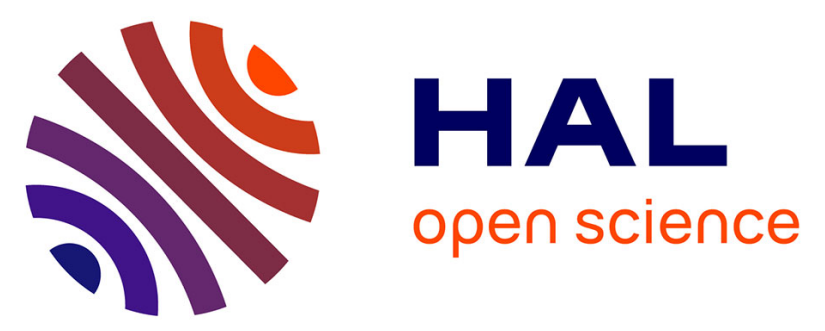

\title{
MicroRNA in the ovine mammary gland during early pregnancy: spatial and temporal expression of miR-21, miR-205, and miR-200
}

Laurent Galio, Stephanie S. Droineau, Patrick P. Yeboah, Hania H. Boudiaf, Stephan S. Bouet, Sandrine S. Truchet, Eve Devinoy

\section{To cite this version:}

Laurent Galio, Stephanie S. Droineau, Patrick P. Yeboah, Hania H. Boudiaf, Stephan S. Bouet, et al.. MicroRNA in the ovine mammary gland during early pregnancy: spatial and temporal expression of miR-21, miR-205, and miR-200. Physiological Genomics, 2013, 45 (4), pp.151-161. 10.1152/physiolgenomics.00091.2012 . hal-01000754

\section{HAL Id: hal-01000754 https://hal.science/hal-01000754}

Submitted on 29 May 2020

HAL is a multi-disciplinary open access archive for the deposit and dissemination of scientific research documents, whether they are published or not. The documents may come from teaching and research institutions in France or abroad, or from public or private research centers.
L'archive ouverte pluridisciplinaire HAL, est destinée au dépôt et à la diffusion de documents scientifiques de niveau recherche, publiés ou non, émanant des établissements d'enseignement et de recherche français ou étrangers, des laboratoires publics ou privés. 


\title{
MicroRNA in the ovine mammary gland during early pregnancy: spatial and temporal expression of miR-21, miR-205, and miR-200
}

\author{
Laurent Galio, ${ }^{1}$ Stéphanie Droineau, ${ }^{1}$ Patrick Yeboah, ${ }^{1}$ Hania Boudiaf, ${ }^{1}$ Stephan Bouet, ${ }^{2,3}$ \\ Sandrine Truchet, ${ }^{1}$ and Eve Devinoy ${ }^{1}$ \\ ${ }^{1}$ Institut National de la Recherche Agronomique (INRA), Unité de Recherche 1196 Génomique et Physiologie de la Lactation, \\ Jouy-en-Josas, France; ${ }^{2}$ INRA-AgroParisTech, Unité Mixte de Recherche 1313 Animal Genetics and Integrative Biology, \\ Jouy-en-Josas, France; and ${ }^{3}$ Commissariat à l'énergie Atomique et aux Energies Alternatives, Direction des Sciences du \\ Vivant, Institut de radiobiologie Cellulaire et Moléculaire, Service de Radiobiologie et Innovations Technologiques, \\ Laboratory of Radiobiology and Genomics Studies, Jouy-en-Josas, France
}

Submitted 9 July 2012; accepted in final form 26 December 2012

Galio L, Droineau S, Yeboah P, Boudiaf H, Bouet S, Truchet S, Devinoy E. MicroRNA in the ovine mammary gland during early pregnancy: spatial and temporal expression of miR-21, miR-205, and miR-200. Physiol Genomics 45: 151-161, 2013. First published December 26, 2012; doi:10.1152/physiolgenomics.00091.2012.-The mammary gland undergoes extensive remodeling between the beginning of pregnancy and lactation; this involves cellular processes including cell proliferation, differentiation, and apoptosis, all of which are under the control of numerous regulators. To unravel the role played by miRNA, we describe here 47 new ovine miRNA cloned from mammary gland in early pregnancy displaying strong similarities with those already identified in the cow, human, or mouse. A microarray study of miRNA variations in the adult ovine mammary gland during pregnancy and lactation showed that 100 miRNA are regulated according to three principal patterns of expression: a decrease in early pregnancy, a peak at midpregnancy, or an increase throughout late pregnancy and lactation. One miRNA displaying each pattern (miR-21, miR-205, and miR-200b) was analyzed by qRTPCR. Variations in expression were confirmed for all three miRNA. Using in situ hybridization, we detected both miR-21 and miR-200 in luminal mammary epithelial cells when expressed, whereas miR-205 was expressed in basal cells during the first half of pregnancy and then in luminal cells during the second half. We therefore conclude that miR-21 is strongly expressed in the luminal cells of the normal mammary gland during early pregnancy when extensive cell proliferation occurs. In addition, we show that miR-205 and miR-200 are coexpressed in luminal cells, but only during the second half of pregnancy. These two miRNA may cooperate to maintain epithelial status by repressing an EMT-like program, to achieve and preserve the secretory phenotype of mammary epithelial cells.

miRNA; mammary gland; development; noncoding RNA; pregnancy

MicroRNA (miRNA) belong to a class of evolutionary conserved small RNA (19-25 nucleotides) that regulates gene expression in a sequence-specific manner, essentially at the posttranscriptional level. miRNA then regulate their target genes through either the degradation of messenger RNA (mRNA) or via translational inhibition (4). While subsets (patterns, groups) of miRNA are specifically expressed during early development (5), others are essential for the morphogenesis of certain organs such as the brain (52) or heart (75) or for hematopoietic differentiation (11). Even though tissue-specific miRNA have been described in specific cell types or organs

Address for reprint requests and other correspondence: L. Galio, INRA, UR1196 Génomique et Physiologie de la Lactation, F78352 Jouy-en-Josas, France (e-mail: laurent.galio@ jouy.inra.fr).
$(45,46)$, most miRNA are expressed in several tissues. Each miRNA regulates the expression of hundreds of genes and several proteins in the same pathway, and a single transcript can be targeted by numerous miRNA. Indeed, many miRNA seem to play pivotal roles in important biological processes such as cell proliferation, differentiation, and apoptosis (31). Aberrant miRNA expression has been revealed in the context of numerous diseases, including human breast cancer $(38,72)$.

The mammary gland is a dynamic organ that is unique in its ability to pass through cycles of cell proliferation, differentiation, and apoptosis during adult life (17). miRNA can thus be expected to be involved in mammary gland development, which is predominantly a postnatal process. At birth, rudimentary mammary ducts are already present, derived from the ectodermal mammary placode. During puberty, ovarian and pituitary hormones induce ductal outgrowth and branching, followed by alveolar differentiation during pregnancy and full functional differentiation in the context of parturition and lactation $(32,66,74)$. During mammary gland development, the mammary epithelium invades the stroma in a process that is similar in some respects to that of cancer. After weaning, during the involution phase, the mammary gland regresses and loses a vast majority of its alveoli. Each pregnancy initiates a new round of lobulo-alveolar differentiation. These morphological changes imply multiple cell proliferation cycles, important tissue remodeling, and cell differentiation mechanisms such as mesenchymal-epithelial transition and epithelial-mesenchymal transition (EMT), which are involved in embryo development and metastasis $(2,9,70)$. Indeed, the mammary gland is a complex tissue where the luminal epithelial cells that are synthesizing and secreting milk components form a monolayer that is surrounded by basal epithelial cells and embedded in the stromal tissue composed of adipocytes, blood vessels, and immune cells. Whereas most information to date has focused on human cancer, that describing miRNA in normal mammary gland has remained somewhat limited. Nevertheless, a few studies have investigated the expression of miRNA in nonpathological mammary gland (59). One study investigated miRNA expression throughout mammary gland development in the mouse (1), while other studies revealed subsets of miRNA specifically expressed in progenitor cells from the mouse mammary epithelial cell (MEC) line COMMA-D $\beta G e o$ $(28,36)$. More recently some studies suggested that several miRNA are implicated in mouse mammary gland development $(19,26,47)$, and particularly that certain miRNA are required for the stromal interactions necessary for mouse mammary 
gland development (71). Furthermore, there is mounting evidence to suggest that miRNA are intimately involved in the regulation of hormones and growth factors such as progesterone $(14,15,19)$, estrogen (12), steroid hormones (13), and transforming growth factor (TGF)- $\beta$ (70), which is of considerable importance to mammary gland development. Although this development has been well studied in the mouse, this species does not fully reflect this development in all mammals (35). In particular, the mouse mammary gland develops under the skin in a two-dimensional volume, whereas in ruminants, as well as in humans, it adopts a three-dimensional structure forming the udder or breast, respectively. A few studies have been published on the role of certain miRNA in the mammary gland of lactating cows $(33,48,73)$ or on the presence of miRNA in milk $(30,39)$. One study described cloned miRNA in the mammary gland and adipose tissue of nonpregnant cows (29), and two others focused on miRNA expressed in the mammary gland of lactating goat $(40,41)$. To further this study in ruminants, we therefore analyzed variations in miRNA profiles during pregnancy and lactation. For the purposes of this study, we chose to focus on the sheep (57), which has a 5 -mo pregnancy and in which the physiology and endocrinology of lactation have been very well described $(25,27)$. Ovine mammary gland development has been well described $(16,17$, $24,34,42,64,65)$, as it has in many other types of livestock (57), and more recently the role of multipotent cells in the development, function, and remodeling of the mammary gland has been addressed in this species (18). However, miRNA in ovine mammary gland have not been the subject of much study: only 55 ovine miRNA sequences had been reported in miRBase $(8,22)$ and 203 others described in articles that have not yet been added to miRBase $(3,62)$. We therefore decided to use a sheep model to study miRNA during mammary gland development and particularly during early pregnancy, when an initial burst of mammary cell proliferation occurs (23).

\section{METHODS}

Animals and tissue collection. Ovarian cycles in primiparous ewes of the Prealpes-du-Sud breed were synchronized as previously described (58), using a 14-day treatment of intravaginal sponges containing $40 \mathrm{mg}$ fluorogestone acetate (Intervet, Angers, France). Mammary glands were collected from the abattoir and were then dissected to obtain enriched mammary epithelial tissue. For the microarray analysis, one ewe for each stage studied was killed: at 15 days after estrus (J15), or during pregnancy (P14, P64, P125), or during established lactation (L60). For the RT-qPCR analysis, four animals per stage (P14, P35, P55, P100, P125) were also killed. For in situ hybridization, two blocks of two animals per stage were prepared. CD1 mice were bred at Institut National de la Recherche Agronomique (INRA; UE0907 IERP Infectiologie Expérimentale des Rongeurs et Poissons, Jouy-en-Josas, France). They were killed by cervical dislocation at different physiological stages (one animal per stage); namely virgin (at least $8 \mathrm{wk}$ after birth), mid- and late pregnancy (P10 and P17, respectively) and early and full lactation (L2 and L10, respectively), and the inguinal mammary glands were excised immediately. All principles of good laboratory animal care were followed, and procedures were carried out in accordance with institutional and French guidelines (authorization level 1 ref. 78-21 valid until 28 May 2013). For RNA extraction, the tissues were snap-frozen immediately in liquid nitrogen and kept at $-80^{\circ} \mathrm{C}$. For in situ hybridization, the tissues were fixed for $10 \mathrm{~min}$ at room temperature in $4 \%$ paraformaldehyde (PFA) in phosphate buffer saline (PBS) ( $\mathrm{pH} 7.5$ ), incubated at $4^{\circ} \mathrm{C}$ overnight in $40 \%$ sucrose in PBS, embed- ded in Tissue-Tek (Sakura), frozen in liquid nitrogen and stored at $-80^{\circ} \mathrm{C}$.

Total RNA extraction and purification. We homogenized 100-150 mg of snap-frozen mammary tissue samples in $1 \mathrm{ml}$ TRIZOL Reagent (Invitrogen) using an Ultra-turrax and then incubated it for $5 \mathrm{~min}$ at room temperature to allow the complete dissociation of nucleoprotein complexes. An $0.2 \mathrm{ml}$ volume of chloroform was added, and the samples were shaken vigorously for $15 \mathrm{~s}$, incubated at room temperature for 2-3 $\mathrm{min}$, and then centrifuged at $10,000 \mathrm{~g}$ for $15 \mathrm{~min}$ at $4^{\circ} \mathrm{C}$. The aqueous phase was transferred to a fresh tube, and the total volume of samples was measured. After the addition of three volumes of absolute ethanol, to retain the small RNA, the RNA solution was purified using the NucleoSpin RNA clean-up kit (Macherey-Nagel), according to the manufacturer's guidelines. The quantity and integrity of RNA were estimated with a NanoDrop spectrophotometer (NanoDrop Technologies) and Agilent 2100 Bioanalyzer (Agilent Technologies), respectively.

Isolation of small RNA and construction of a cDNA library. RNA were extracted from the ewe mammary gland in early pregnancy (P14), as described above. The small RNA were recovered selectively by size fractionation using a Microcon YM-30 ultrafiltration device (Millipore). The cDNA library was then constructed as previously described (67), using reverse transcription, polymerase chain reaction and TA cloning in pGEM-T plasmid (Promega). Sequencing was performed by Eurofins MWG Operon.

Locked nucleic acid-modified oligonucleotides. Locked nucleic acid (LNA)-modified DNA probes were synthesized by Eurogentec. The sequences of the LNA-modified oligonucleotides, complementary to the miRNA sequences, were as follows (LNA-modified bases in upper case): miR-21: cAacAtcAgtCtgAtaAgcTa; mutated miR-21: cAacTtcAgtGtgAtaAgcAa; miR-205: cAgaCtcCggTggAatGaaGga; mutated miR-205: cTgaGtcCggTggAatCaaCga; miR-200b: tCatcAttaCcAgGcagtAtta; mutated miR-200b: tGatcAttaCcAgCcagtTtta.

MicroRNA expression analysis. MicroRNA expression was analyzed in total RNA extracted from the mammary gland of one animal per stage by Beckman Coulter Genomics. Target labeling, hybridization, washing, scanning, and data extraction were performed according to protocols established by the manufacturer for mouse miRNA microarrays [Mouse miRNA Microarray (V2), Agilent Technologies]. The scanned images were analyzed with Feature Extraction Software (Agilent Technologies) using default parameters for miRNA arrays to obtain background-subtracted and spatially detrended Processed Signal intensities. Features flagged in Feature Extraction as Feature Nonuniform outliers were kept as such. Intensity data were normalized with Rosetta Resolver (ver. 7.2), using the Agilent/miRNAIntensity Profile Builder. This process starts from raw scan data and processes reporter and sequence-level intensity profiles. This pipeline implements summarization from feature data as described in the Agilent Feature Extraction Software (v9.5) Reference Guide, 4th ed., 2007, 237-239. The signal values of features are summarized to their reporter as a gTotalProbeSignal sum, and reporters are summarized to their sequence as a sum. Following this step, the Agilent/miRNAIntensity Experiment Builder was used to achieve group-level normalization, added to a 75th percentile scaling operation during the "normalize intensities" step (Inter-chip Scaling plug-in).

Microarray data analysis (Beckman Coulter Genomics). Agglomerative cluster analysis was performed on intensity data for each miRNA sequence, keeping the chronological order of stages. Filtering was based on including only those sequences with at least three intensity definitions (ED) and complying with a $P$ value $\leq 0.01$. Only EDs in which at least one sequence was present and which complied with the above thresholds were included.

MicroRNA RT-qPCR analysis. miRNA were quantified by RTqPCR using TaqMan MicroRNA Expression Assays (Applied Biosystems) in four animal per stage (P14, P35, P64, P100, P125). Depending on the miRNA sequences in sheep, different miRNA Taqman kits (Applied Biosystems) were selected: miR-21 (bta-miR- 
21, cat\# 4440886), miR-205 (hsa-miR-205/mmu-miR-205, cat. \#4427975) and miR-200b (bta-miR-200b, cat. \#4440886). In brief, 5 ng of total RNA were reverse transcribed under the following conditions (Taqman microRNA RT kit, Applied Biosystems): $16^{\circ} \mathrm{C}$ for 30 $\min , 42^{\circ} \mathrm{C}$ for $30 \mathrm{~min}, 85^{\circ} \mathrm{C}$ for $5 \mathrm{~min}$. The PCR reactions were as follows (Taqman Universal Mmix II kit, Applied Biosystems): $95^{\circ} \mathrm{C}$ for $10 \mathrm{~min}$ followed by 40 cycles of $95^{\circ} \mathrm{C}$ for $15 \mathrm{~s}$ and $60^{\circ} \mathrm{C}$ for $1 \mathrm{~min}$ using the Mastercycler ep Realplex (Eppendorf), with three technical repetitions per point. RNU6B was used for normalization (RNU6B, assay ID 001093, Applied Biosystems). The relative abundance was multiplied by 1,000 . Normalized data were plotted for each stage (means $\pm \mathrm{SE}$ ).

Statistical analysis. Statistical analyses were performed on RTqPCR data, obtained from four animals per stage, to determine stages that were statistically different $(P \leq 0.05)$, using the Mann-Whitney $U$-test (63).

In situ hybridization. We digoxigenin (DIG)-labeled 100 pmol of miR-21 LNA-probes using the $3^{\prime}$-terminal transferase labeling kit (Roche Diagnostics) for $30 \mathrm{~min}$ at $37^{\circ} \mathrm{C}$. In situ hybridization was adapted from the technique described by Obernosterer et al. (54). In brief, $7 \mu \mathrm{m}$ sections were postfixed for $10 \mathrm{~min}$ in $4 \%$ PFA in PBS $(\mathrm{pH}$ $7.5)$, acetylated for $10 \mathrm{~min}(100 \mathrm{mM}$ triethanolamine, $21 \mathrm{mM} \mathrm{HCl}$, $26.5 \mathrm{mM}$ anhydride acetic acid), and finally digested with $5 \mu \mathrm{g} / \mathrm{ml}$ proteinase $\mathrm{K}$ (Roche Diagnostics) for $5 \mathrm{~min}$. The sections were prehybridized for $30 \mathrm{~min}$ at room temperature in $50 \%$ formamide, $5 \times$ SSC, $5 \times$ Denhardt's solution $200 \mu \mathrm{g} / \mathrm{ml}$ yeast RNA, $500 \mu \mathrm{g} / \mathrm{ml}$ salmon sperm DNA, and $20 \mu \mathrm{g} / \mathrm{ml}$ Roche blocking reagent and then hybridized in the same buffer supplemented with $0.25 \%$ CHAPS and $0.1 \%$ Tween 20 and the probes, for $1 \mathrm{~h}$ at either $50^{\circ} \mathrm{C}$ (for miR-21 and miR-200b probes) or $55^{\circ} \mathrm{C}$ (for miR-205 probes). The sections were then washed three times for $15 \mathrm{~min}$ in $0.2 \times \mathrm{SSC}$ at a temperature $3^{\circ} \mathrm{C}$ higher than that used for hybridization. The sections were then equilibrated sequentially in $100 \mathrm{mM}$ Tris $\mathrm{pH} 7.5,150 \mathrm{mM} \mathrm{NaCl}$ (buffer A) for $10 \mathrm{~min}$, blocked in buffer A supplemented with $10 \%$ fetal calf serum and $0.05 \%$ Tween 20 for $30 \mathrm{~min}$ and finally incubated for $1 \mathrm{~h}$ in anti-DIG antibody (anti-DIG-PA Fab fragments, Roche Diagnostics) diluted to $1 / 2,000$ with blocking solution. After three washes in buffer $A$, the sections were equilibrated for $10 \mathrm{~min}$ in 100 $\mathrm{mM}$ Tris $\mathrm{pH}$ 9, $100 \mathrm{mM} \mathrm{NaCl}, 50 \mathrm{mM} \mathrm{MgCl}_{2}$. Phosphatase activity was revealed using nitro-blue tetrazolium chloride/5-bromo-4-chloro$3^{\prime}$-indolyphosphate p-toluidine-stabilized solution (Eurobio) for 1-3 days, depending on the miRNA detected. The sections were finally mounted in $80 \%$ glycerol or in Diamount mounting medium (Diapath) for nanozoomer scanning.

Immunohistochemistry. Cytokeratins 8 and 14 were localized by immuno-histochemical analyses using the following antibodies: monoclonal anti-mouse CK14 (1:100) (clone LL002, Thermo Scientific), monoclonal anti-mouse CK8 (1:100) (clone 1E8, Covance), donkey anti mouse-TRITC (1:300), and rabbit anti-mouse-FITC (1: 300) antibodies (both from Jackson Immunoresearch). In brief, 7-mm frozen sections were treated in $50 \mathrm{mM}$ ammonium chloride for $1 \mathrm{~h}$ followed by permeabilization and blocking in $2 \%$ BSA, $0.05 \%$ saponin, and $10 \%$ donkey serum in PBS $1 \times$ for $1 \mathrm{~h}$. They were then incubated at $4{ }^{\circ} \mathrm{C}$ overnight with the primary antibody (monoclonal anti-mouse CK14) diluted in the same buffer. Tissue sections were then incubated for $1 \mathrm{~h}$ at room temperature with secondary antibody (donkey anti mouse-TRITC). After blocking for $1 \mathrm{~h}$ in $2 \%$ BSA, $0.05 \%$ saponin, and $10 \%$ rabbit serum in PBS $1 \times$, frozen sections were incubated with the second primary antibody (monoclonal antimouse CK8) overnight at $4^{\circ} \mathrm{C}$, and finally with the corresponding secondary antibody (rabbit anti mouse-FITC) $1 \mathrm{~h}$ at room temperature. The sections were mounted in Vectashield including DAPI.

Image acquisition. Photonic microscopy for the in situ hybridizations was performed with a Leica Leitz DMRB at the MIMA2 Platform (INRA Jouy-en-Josas, France, http://mima2.jouy.inra.fr/ mima2) using a $\times 63$ oil-immersion objective (NA 1.3) and a chargecoupled device DP50 imaging camera (Olympus) coupled to the
Cell $^{\wedge}$ F software (Olympus) (Fig. 4). The in situ hybridizations shown in Fig. 5 were digitalized with a Hamamatsu nanozoomer (Tokyo, Japan), which enabled observation of the entire section. The images were analyzed with the Hamamatsu Nanozoomer Digital Pathology Virtual Slide Viewer. For the immunochemistry experiments (Fig. 5), the slides were observed under an AxioObserver.Z1 microscope equipped with a structured illumination system (Zeiss Apotome). Images were acquired using the AxioVision 4.6 software (Zeiss). Apotome observations were performed at the Mima2 facilities in Jouy-en-Josas (France).

Morphological measurements. The surface areas of acini and the height of epithelial cells were measured on in situ hybridized sections digitalized using a Hamamatsu nanozoomer (Tokyo, Japan), under NDP viewer software. Statistical analyses were performed on the measurements (521 elements for acini, 152 for epithelial cells) obtained from two animals per stage (P15 and P117) to determine whether these criteria differed in a statistically significant manner between the two stages. Both Student's $t$-test and permutation tests produced highly significant $P$ values.

\section{RESULTS}

Sequence analysis of miRNA cloned from ewe mammary gland at 14 days of pregnancy (early pregnancy). RNA smaller than 60 bases were isolated from ovine mammary gland collected on day 14 of pregnancy, when the proliferation of MEC is very high (23). A cDNA library was prepared in Escherichia coli. From the 496 bacterial clones that were sequenced, 211 were relevant and contained both $5^{\prime}$ and $3^{\prime}$ introduced adaptors (EBI ID: HE599804 to HE600014). Of these 211 clones, 146 corresponded to 54 separate sequences that were similar to the miRNA sequences already described in the Sanger miRBase (http://www.mirbase.org/, see Supplemental Table S1), with differences of only one or two nucleotides at their 3 '-ends. Of these, miR-27e and miR-36a were identified for the first time in mammals. Moreover, among the 54 miRNA present in the Sanger miRBase, only miR-379 was already referenced as an ovine miRNA (8) and six others (let-7b, let-7c, miR-21, miR26a, miR-29a, and miR-125b) were present in miRBase, but not yet described as an ovine miRNA, although already published as such (62). We were therefore able to describe 47 new ovine miRNA.

Among the 65 sequences which had no clear similarity with any miRNA described in miRBase, 14 sequences were between 19 and 25 nucleotides in length. One of them was similar to a sequence previously identified as miR-1308 in humans and pigs, but which was more recently characterized as a fragment of a tRNA and had therefore been removed from the Sanger database. Six other sequences displayed similarities with known miRNA, but differed by at least three nucleotides. Finally, seven clones corresponding to five different sequences displayed no similarity with miRNA that have already been described and could thus be novel miRNA. Finally, 51 others, longer than 25 nucleotides, could not be considered as miRNA.

Of the 54 different ovine miRNA that we cloned (see Table 1) and that exhibited similarity with miRNA already described in miRBase, four were cloned 10 times or more (miR-21, 18 clones; let-7a, 14 clones; let-7b, 13 clones; miR-99a, 10 clones). MiR-21 was cloned 18 times with no ambiguity regarding its sequence except for the two last nucleotides, a known drawback of the cloning method used (46). The prevalent occurrence of miR-21 suggests that it may be highly represented in the mammary gland at the beginning of pregnancy. We cloned 23 miRNA between 
Table 1. Occurrence of each miRNA cloned from ovine mammary gland at 14 days of pregnancy

\begin{tabular}{|c|c|c|c|}
\hline Names of Cloned miRNA & $\begin{array}{l}\text { Occurrence of } \\
\text { Each miRNA }\end{array}$ & $\begin{array}{l}\text { Previously } \\
\text { Described in } \\
\text { Mammary Gland }\end{array}$ & $\begin{array}{c}\text { New in } \\
\text { Mammary Gland }\end{array}$ \\
\hline 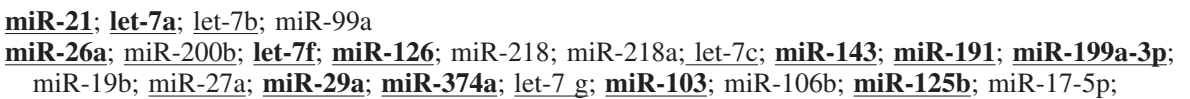 & $n>10$ & 3 & 1 \\
\hline 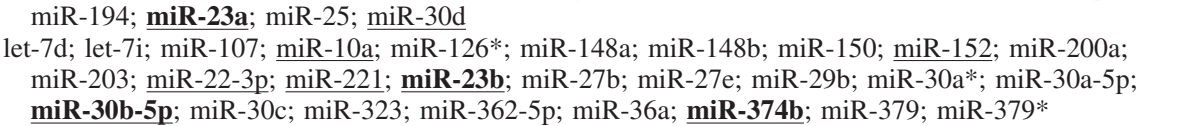 & $2<n<10$ & 17 & 20 \\
\hline
\end{tabular}

Boldfaced microRNA (miRNA or miR) had also been cloned by Gu et al. (29), in the mammary gland of Holstein cows. Underlined miRNA have already been described in the mammary gland.

two and 10 times. Among these, miR-26a, miR-200b, and let-7f were cloned seven, six, and five times, respectively; 27 sequences were cloned only once.

However, cloning is not a quantitative method, as has already been discussed with respect to the results obtained in the pig (51) and in Arabidopsis (68). This cloning step was essential to determine if available mouse microarray tools were relevant for ovine studies, as no tools were yet available for ovine miRNA. As a large number of miRNA sequences are conserved between ovine and mouse (see above), we chose to evaluate miRNA accumulation levels by heterologous hybridization on a mouse miRNA microarray, as this technique had previously been shown to be very reliable (69).

Microarray miRNA expression profiles at five stages of ovine mammary gland development. Using a 567 element mouse miRNA oligoarray (Agilent mouse miRNA microarray Version 2), we established miRNA expression patterns for ovine mammary glands at five different developmental stages, namely: cycling (J15); early (P14), mid- (P64), and late pregnancy (P125); and established lactation (L60). Data are available on the Gene Expression Omnibus (GEO) database (GEO ID: GSE32654).

We performed agglomerative cluster analysis on intensity data for each miRNA sequence, keeping the chronological order of stages. The results are depicted in Fig. 1. Two major branches were apparent, one of which (Fig. 1, left) corresponded to miRNA (59 miRNA, 43\%) with increased expression concomitant with physiological development of the mammary gland, especially during late pregnancy (P125) and lactation (L60). The other branch corresponded to the majority of miRNA (78 miRNA, 57\%), which displayed decreased expression during the physiological stages of mammary gland development (Fig. 1, right). Differential miRNA expression across developmental stages could also be observed within each branch. Seven clusters (clusters $1-3$ in branch 1 and clusters 4-7 in branch 2) could be separated and are summarized below.

The expression of members in clusters 1 and 2 was induced during lactation (L60), although some of them had already increased during late pregnancy (P125) (some miRNA in cluster 1), while others showed a transient peak of expression at midpregnancy (most miRNA in cluster 2). Members in cluster 3 displayed a peak of expression during late pregnancy (P125). Members in cluster 4 shared a peak of expression at midpregnancy (P64), in most cases with an increase in expression during early pregnancy (P14). Members in cluster 5 already exhibited marked expression in cycle (J15) and early pregnancy (P14), with peak expression during midpregnancy (P64) for most of them. Cluster 6 appeared to be a mix of the patterns found in clusters 3, 4, and 5, with downregulation during late pregnancy (P125) being a common feature. Finally, members in cluster 7 displayed a high level of expression during cycle (J15) but were downregulated at midpregnancy (P64).

These results were then compared with those obtained by homologous hybridization of mouse mammary gland miRNA obtained at comparable physiological stages using the same Agilent mouse microarray.

Microarray miRNA expression profiles at five developmental stages of mouse mammary gland. Using the same mouse miRNA oligoarray (Agilent mouse miRNA microarray Version 2), we established miRNA expression patterns for mouse mammary gland at five different developmental stages: virgin (V); mid- (P10) and late pregnancy (P17); early (L2) and late lactation (L10). Data are available on the National Center for Biotechnology Information GEO (GEO ID: GSE32654).

Agglomerative cluster analysis was performed on intensity data, as previously described for the ewe. The results are depicted in Fig. 2. Two major branches were apparent, reminiscent of those observed in the ewe (Fig. 1). The expression of some miRNA was increased during different mammary developmental stages, especially during late pregnancy and lactation (54 miRNA, 50\%; Fig. 2, right), whereas other miRNA displayed a decreased expression (54 miRNA, 50\%; Fig. 2, left). Differential miRNA expression across developmental stages was also observed, and seven clusters could be separated.

The cluster distributions obtained from these experiments were markedly similar to those observed in the ewe, demonstrating that, within the framework of our experiments, heterologous hybridization produced informative data.

Finally, 98 miRNA were found to be common between the 131 differentially expressed miRNA in ovine mammary gland and the 108 differentially expressed miRNA in our mouse microarray results. Of these 98 common miRNA, 39 miRNA displayed similar expression profiles in both species. Surprisingly, we identified more differentially expressed miRNA with a heterologous ovine microarray (ovine miRNA hybridized to mouse microarray) than with homologous hybridization. These discrepancies may be related to differences in mammary gland development between the two species studied. However, it may also have been due to the fact that no early pregnancy samples were tested during the mouse experiment, thus reducing the amplitude of differential expression. 


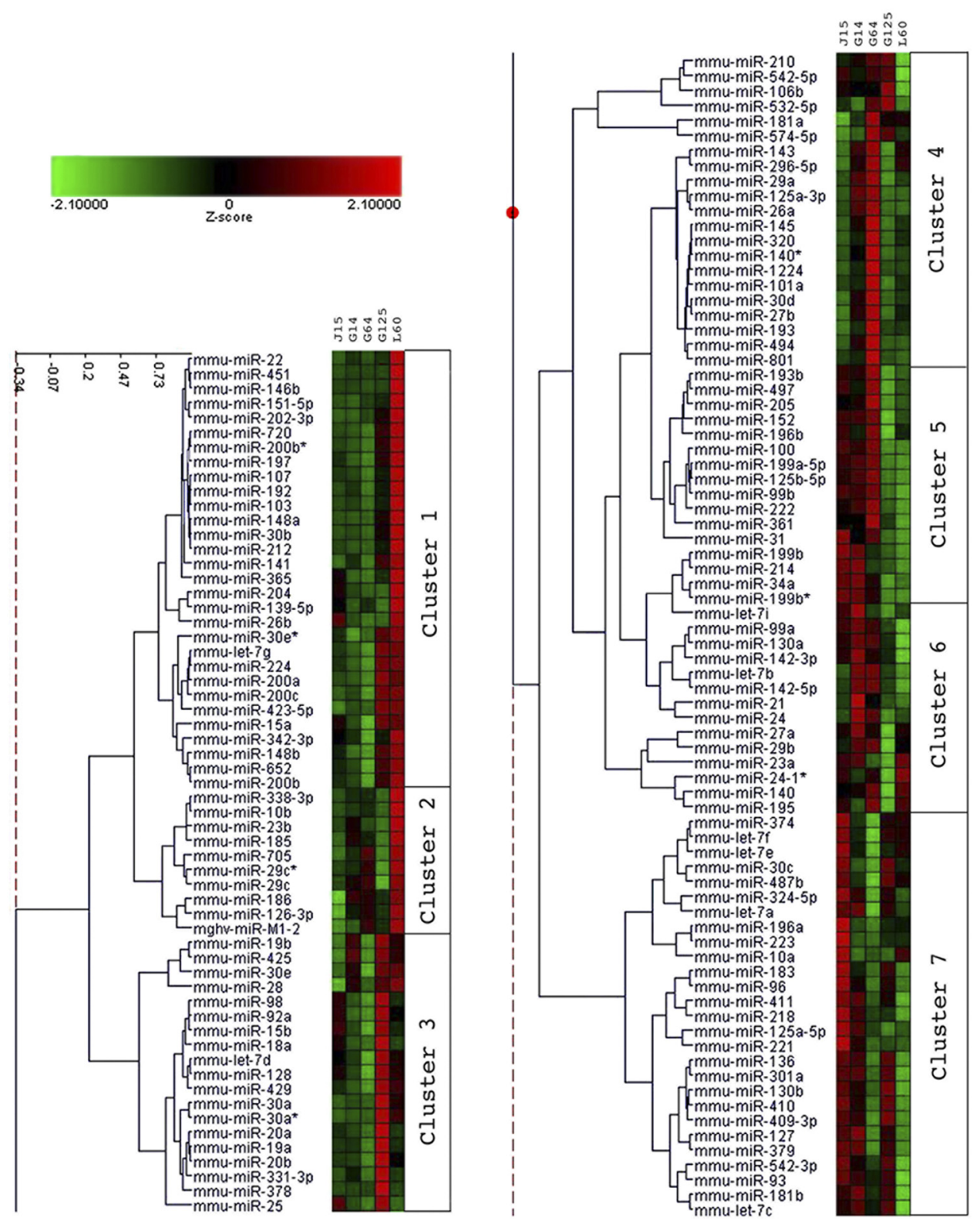

Fig. 1. Agglomerative cluster analysis of ovine mammary gland microRNA (miRNA) microarray results. miRNA expression patterns were established for ovine mammary glands at 5 different developmental stages, namely: cycling (J15); early (G14), mid- (G64), and late pregnancy (G125); and established lactation (L60). Agglomerative cluster analysis was performed on intensity data from each miRNA, keeping the samples in order so as to comply with the physiological process in the mammary gland.

Expression levels of miR-21, miR-205, and miR-200b throughout ovine mammary gland development. Three major patterns of miRNA expression were selected from the ovine and murine microarray results. First, a cluster of miRNA that were downregulated during pregnancy (cluster 6 in ewe, cluster 2 in mouse); second, a cluster with its expression induced during pregnancy (cluster 5 in ewe, cluster 7 in mouse); and third, a cluster with its expression induced during lactation (cluster 1 in ewe, cluster 5 in mouse). One miRNA representative of each selected cluster was then chosen: miR-21 (cluster 6 in ewe, cluster 2 in mouse), miR-205 (cluster 5 in ewe, cluster 7 in mouse), and miR-200b (cluster 1 in ewe, cluster 5 in mouse).

We furthered the above studies regarding the expression of miR-21, miR-205, and miR-200b during pregnancy (P14, P35, P55, P100, and P125) with Taqman RT-qPCR in four animals per stage. Normalized data, vs. U6 spliceosomal snRNA, were plotted for each stage (means \pm SE) (Fig. 3). The expression of miR-21 was stronger at the beginning of pregnancy (P14 and P35), falling at P55 $(P \leq 0.05)$ and then gradually declining toward the end of pregnancy. miR-205 was strongly detected during the first half of pregnancy with a marked decrease later on $(P \leq 0.05)$. The expression of miR-200b displayed a relative stability throughout pregnancy with a slight increase at P125, which was in agreement with the microarray data.

Tissue localization of miR-21, miR-205, and miR-200 during ovine mammary gland development. To study the cellular origin of the three representative miRNA (miR-21, miR-205, and miR-200), we performed in situ hybridizations on ovine mammary gland sections at the same physiological stages as those used in RT-qPCR experiments.

Globally, the signal was mainly observed in epithelial or myoepithelial cells rather than in the stroma. The signal in stromal tissue was mainly observed with the miR-200b probe. However, the signal was weaker in the stroma than in the epithelial compartment (Fig. 4). This may have been due to 
Fig. 2. Agglomerative cluster analysis of mouse mammary gland miRNA microarray results. miRNA expression patterns were established for mouse mammary glands at five different developmental stages: virgin (V); mid- (G10) and late pregnancy (G17); early (L2) and late lactation (L10). Agglomerative cluster analysis was performed on intensity data from each miRNA, keeping the samples in order so as to comply with the physiological process in the mammary gland.

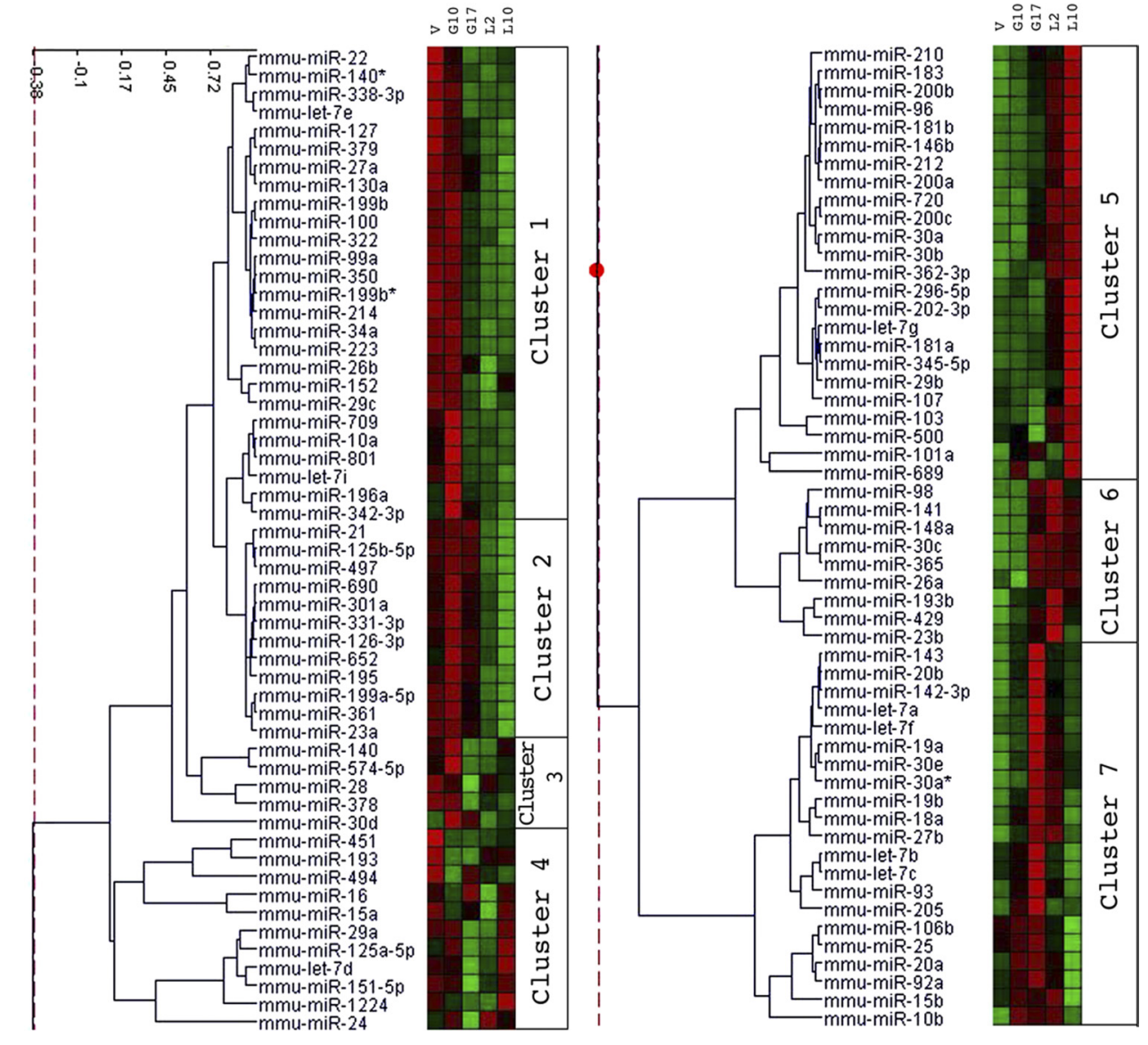

nonspecific binding of the probes, although weak miRNA expression could not be totally ruled out.

miR-21 expression was observed in luminal epithelial cells in the mammary gland of nonpregnant ewes (data not shown) and during early stages of pregnancy (see P15, Fig. 4), while it appeared to be weaker during the mid- and late pregnancy stages (data not shown). miR-200 was very difficult to observe by in situ hybridization. The signal intensity of the specific probe was comparable to that of mutated probe, but when observed, it was only seen in luminal epithelial cells (see P117,
Fig. 3. miR-21, miR-205, and miR-200b expression changes in ewe mammary gland during pregnancy, by quantitative RT-PCR. The relative expression of miR-21, miR-205, and miR-200b was determined by RT-qPCR at different stages of pregnancy. Each miRNA expression was normalized to U6 expression: at 14 days (P14), 35 days (P35), 55 days (P55), 100 days (P100), and 125 days (P125) of pregnancy. Normalized data were plotted for each miRNA (means of 4 animal per stage $\pm \mathrm{SE}$ ) in blue for P14, in red for P35, in green for P55, in purple for P100, and in gray for P125 (each point with $n=$ 3 technical repetitions). The results of the Mann-Whitney $U$-test are presented at top left.

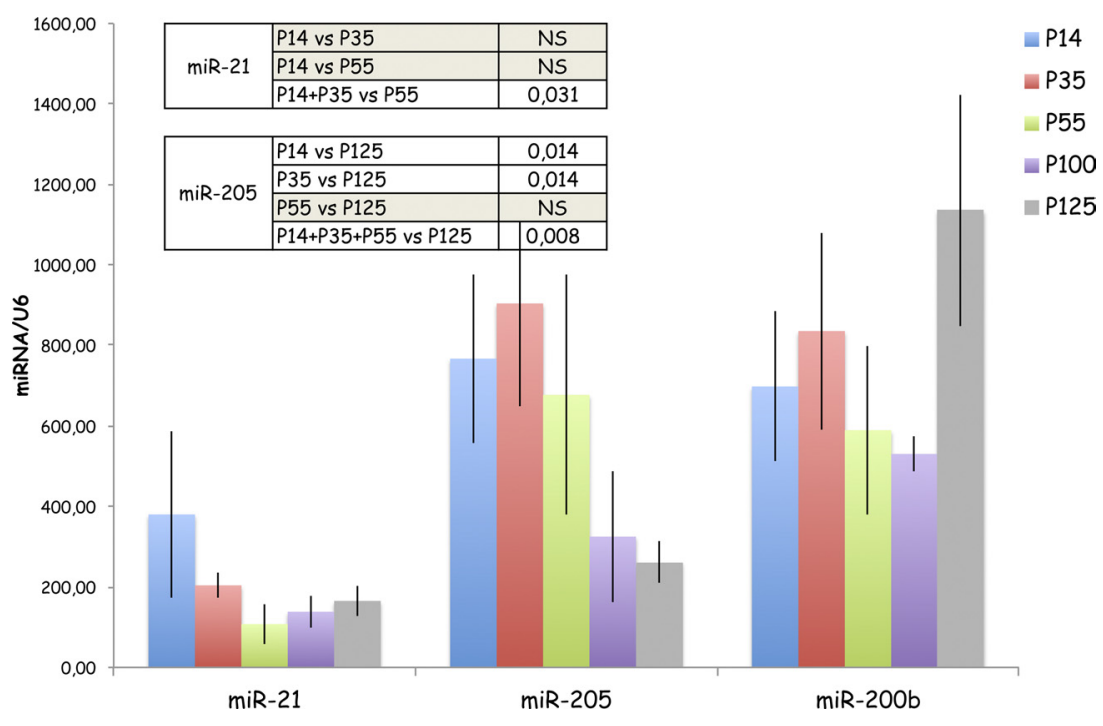




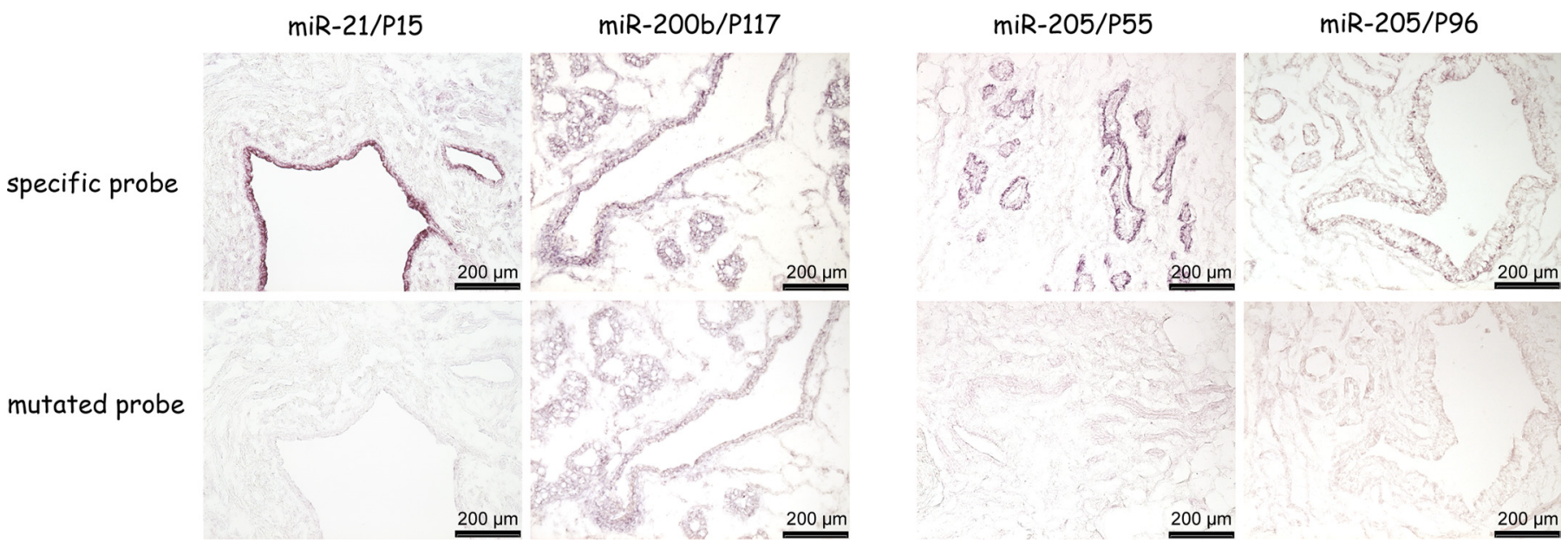

Fig. 4. Expression of miR-21, miR-200b, and miR-205 detected by in situ hybridization on ewe mammary gland sections at different stages of development. A: detection of miR-21 and miR-200b expression was determined by in situ hybridization with a digoxigenin (DIG)-labeled oligo locked nucleic acid (LNA) probe for each miRNA. A negative control was performed by using 1 LNA probe mutated on several LNA bases for each miRNA. The stages with the strongest signal during the in situ experiment (in agreement with the microarray and the quantitative RT-qPCR experiments) are presented here (P15 for miR-21 and P117 for miR-200b). B: miR-205 expression was detected by in situ hybridization with a DIG-labeled oligo LNA probe. A negative control was performed by using 1 LNA probe mutated on several LNA bases. Two stages of pregnancy representative of localization changes are presented here (P55 and P96).

Fig. 4). miR-205 was strongly expressed in basal cells in the nonpregnant ewe (data not shown) and during the early and midpregnancy stages (see P55, Fig. 4). As the signal surrounding luminal epithelial cells is still present at midpregnancy when most basal epithelial have fulfilled their transition to a myoepithelial cell type, miR205 is surely also expressed in myoepithelial cells and was also expressed at later stages in the luminal epithelial cells of most mammary ducts more than in acini (see P96, Fig. 4). At P96 or P117, both the size of epithelial cells and the surface areas of acini were generally higher than at earlier stages: $11.54 \mu \mathrm{m} \pm 0.33$ at P117 vs. 6.35 $\mu \mathrm{m} \pm 0.19$ at $\mathrm{P} 15$, with a $P<0.0001$ and $3,068.14 \pm 177.82$ at $\mathrm{P} 117$ vs. $993.88 \mu \mathrm{m} \pm 43.66$ at $\mathrm{P} 15$, with a $P<0.0001$, respectively (means $\pm \mathrm{SE}$ ). These findings were in agreement with an earlier study that had shown that the highest percentage of epithelial tissue in the mammary glands of ewes was reached at around day 115 of pregnancy, and that this period was also associated with an increase in epithelial cell size (65).

Although they were not quantitative, the signal intensities observed agreed with the findings of both microarray and RT-qPCR experiments. Taken together, our results suggest that miR-21 and miR-200 were mainly expressed in the luminal epithelial cell layer, whereas miR-205 was expressed in either basal or luminal cells, depending on the time point considered.

A general view of a 15-day pregnancy section (Fig. $5 A$ ) after miR-205 detection by in situ hybridization showed that this miRNA was expressed in all mammary structures. A zoom revealed that it was expressed in both ducts and acini. To determine the cellular type in which miR-205 is expressed, immunohistochemistry experiments were performed on sections from the same block (Fig. 5B) treated with specific antibodies to detect both cytokeratin 8 (CK8) and cytokeratin 14 (CK14) being specifically expressed in luminal and basal MEC, respectively. Figure $5 B$ depicts the staining of one mammary duct (left) and two acini (right). The labeling obtained with anti-CK14 was closely comparable to that seen with miR-205 in situ detection, suggesting that this miRNA is expressed in basal epithelial cells.

\section{DISCUSSION}

We cloned 54 ovine miRNA, among which 47 had not previously been described in this species. Their occurrence in our library ranged from 1 to 18 , and their sequences were markedly similar to the miRNA sequences described in cows, humans and mice (miRBase, see Supplemental Table S1). ${ }^{1}$ They could therefore be considered as conserved miRNA between mammalian species. Among them, 16 miRNA had also been cloned by Gu et al. (29) in mammary glands from nonpregnant Holstein cows (Supplemental Table S2): let-7a, let-7f, miR-103, miR-125B, miR-126, miR-143, miR-191, miR-199a, miR-21, miR-23a, miR-23b, miR-26a, miR-29a, miR-30b, miR-374a, miR-374b.

Another 11 miRNA cloned during our experiments had also been cloned by Gu et al. (29), but only in adipose tissue: let-7b, let-7c, let-7i, miR-10b, miR-126*, miR-17-5p, miR-19b, miR25, miR-27b, miR-30d (Supplemental Table S2). However, in our experiments in midpregnancy, most of these miRNA were detected not only in both total ewe and mouse mammary glands but also in mouse epithelial cell-enriched population prepared by collagenase digestion and low-speed centrifugation steps as previously described by our laboratory (10) by a protocol adapted from Pullan et al. (56), suggesting that their expression is not restricted to adipose tissue (data not shown). Finally, 30 ovine miRNA cloned during our study had not been cloned by $\mathrm{Gu}$ et al: let-7d, let-7g, miR-106b, miR-107, miR10a, miR-138b, miR-148a, miR-150, miR-152, miR-181a, miR-194, miR-200a, miR-200b, miR-200c, miR-203, miR218a, miR-22, miR-221, miR-26b, miR-27a, miR-29b, miR30a*, miR-30a-5p, miR-30c, miR-323, miR-362, miR-36a, miR-379, miR-379*, miR-99a (Supplemental Table S2). The expression of 22 of these miRNA was confirmed by microarray experiments in both the ewe mammary gland and mouse mammary gland (data not shown). The expression of five of the

\footnotetext{
${ }^{1}$ The online version of this article contains supplemental material.
} 
A

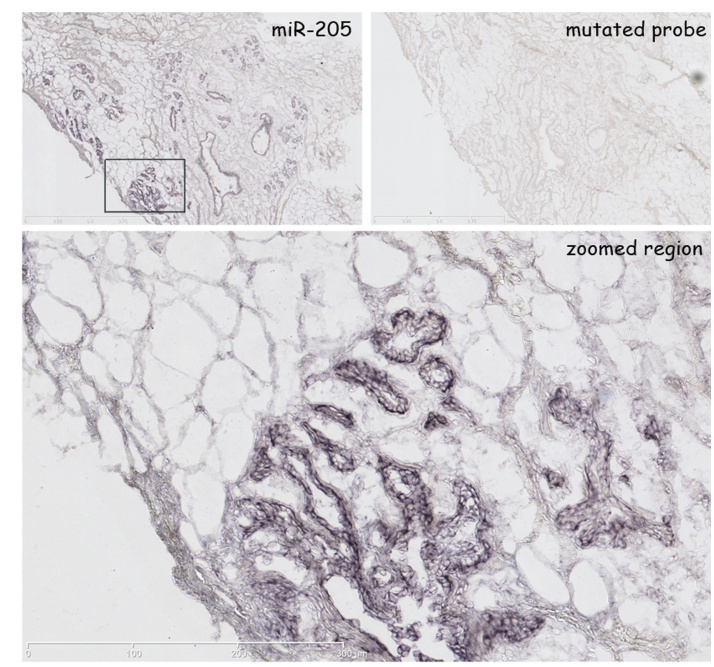

$\mathbf{B}$
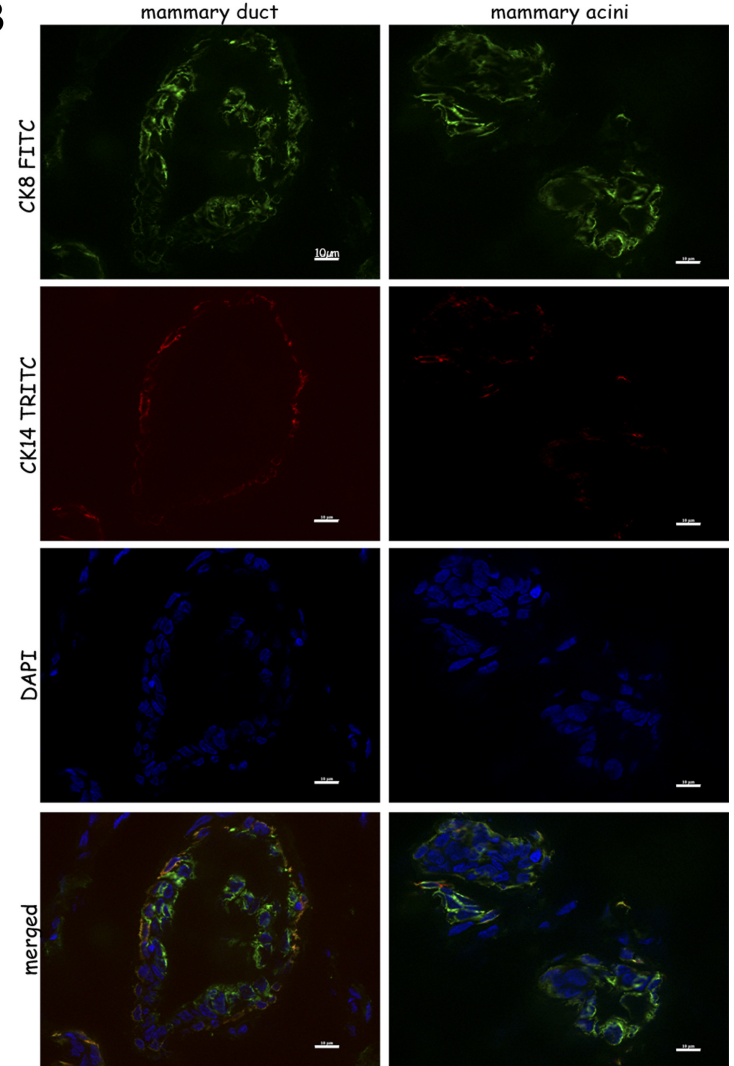

Fig. 5. Detection of miR-205 expression at 14 days of pregnancy using in situ hybridization and immunodetection with anti-CK8 and anti-CK14 antibodies. A: miR-205 expression was revealed by in situ hybridization. A global view of the same region hybridized with either the miR-205 LNA probe or the mutated probe and a zoomed region (squared region) $B$ : epithelial and myoepithelial cells were revealed by immunodetection in ewe mammary gland at 14 days pregnancy using either anti-CK14 (FITC) or anti-CK8 (TRITC) antibodies, respectively. Nuclei were detected with DAPI. The staining obtained with 1 mammary duct is represented in the left column and with 2 acini in the right column.

miRNA we cloned was undetectable (miR-194, miR-203, miR218a, miR-323, and miR-362), even though these miRNA were present on the microarray chip, suggesting that their expression levels may be extremely low.

Each miRNA gene was localized on the bovine genome (Bta 4.0 ), in the absence of any ovine genome assembly, and the list of the miRNA genes located in their vicinity was collected from the Sanger database (miRBase). All the results are summarized in Supplemental Table S3. Similarly, mouse miRNA differentially regulated in our microarray experiments were localized on the mouse genome (NCBIM37), (Supplemental Table S4). On both the bovine and mouse genomes, the genes for the miRNA expressed were localized on many different chromosomes. In the great majority of cases, miRNA which colocalized on one chromosome in one species also colocalized in the other, thus indicating a high degree of miRNA gene conservation. Four exceptions were let-7a, miR-125b, let-7g, and miR-26a, which colocalized on mouse chromosome 9 but were separated on bovine chromosomes 15 (let-7a and miR125b) and 22 (let-7g and miR-26a) in agreement with conserved synteny between mouse and cow chromosomes. Interestingly, most miRNA differentially expressed in the mouse and ovine mammary gland and located within a cluster of miRNA (miRNA genes close together by $10 \mathrm{~kb}$ or less) in one species were located within the corresponding cluster in the other species. The only exceptions were when the number of copies of miRNA genes was not the same in both species. For example, let-7b was located near the second copy of let-7c in the mouse (which does not exist in the cow) and near the third copy of let-7a in the cow (which does not exist in the mouse).

The differential expression profiles between stages in the ovine mammary gland detected using the microarray approach were confirmed on a selection of three miRNA (miR-21, miR-205, and miR-200b) by RT-qPCR with four animals per stage (P14, P35, P55, P100, P125). The microarray results we obtained in sheep were fairly comparable to both our results in the mouse and those previously published (1). First, a series of miRNA that had previously been identified as being strongly expressed in a subtype of breast cancer (luminal molecular subtype) (6) was mostly expressed during cycling and pregnancy and was downregulated during lactation in our experiments, as in the study by Avril-Sassen et al. (1). As a second example, all the miRNA families induced during lactation in the Avril-Sassen study (miR-141, miR-200, miR-181, miR148, miR-210) were induced in both our mouse and ewe studies, with the exception of miR-181b, which was not induced during lactation in our experiments.

Our study is an extension to work already published on miRNA expression during mouse mammary gland development (1). Indeed, a comparison of the microarray used by Avril-Sassen's group and our Agilent set revealed that 252 miRNA were common to both sets; 67 were only found in their set and 315 miRNA were only found in the Agilent set that we used. However, taking account of nomenclature changes, only three miRNA, among the 67, were not present in the Agilent set: miR-199a*, miR-422b, and miR-465-3p.

The overexpression of certain oncogenic miRNAs (miR-21, miR-155, miR-10b, miR-373, and miR-520c) and the loss of several tumour suppressor miRNA (miR-206, miR-17-5p, miR-125a, miR-125b, miR-200, let-7, miR-34, and miR-31) have been observed in many types of breast cancer (for a review see Ref. 53). Many of them are regulated during normal mammary gland development, suggesting their function as key regulators and that their balance is crucial to obtaining a functional mammary gland.

The overexpression of miR-21 has been described extensively in many types of cancer, including breast cancer (38, 
61). Furthermore, it has been described as a key miRNA implicated in the control of cell proliferation and as displaying oncogenic activity; it can thus be classified as an oncomiR (60). Here, we showed that miR-21 is abundantly expressed in ewe and mouse mammary glands in nonpregnant animals, as already described in the cow (29), but also at the beginning of pregnancy. Although little change in expression of miR-21 were described during lactation in mouse (1), one study in the cattle showed an upregulation at the onset and early lactation (73). The mammary gland is a complex tissue where the functional acini are embedded in stroma, and miR-21 has been shown to regulate adipogenic differentiation in mesenchymal stem cells through modulation of the TGF- $\beta$ receptor (TGFBR2), at both the mRNA and protein levels (43). Thus the modulation of miR-21 expression that we observed very early in pregnancy in our microarray and quantitative RT-PCR analyses might have been due to changes to mammary gland cell populations (epithelial cells vs. adipocytes) during the course of development. However, in our in situ hybridization experiments, miR-21 expression was mainly observed in luminal epithelial cells. Therefore, because the proportion of epithelial cells increased markedly during pregnancy, the reduction in miR-21 expression could not be explained by a change in the cell population. This strong expression of miR-21 during the first half of pregnancy, corresponding to an intensive phase of proliferation in the mammary gland, is reminiscent of recent findings that showed that miR-21 is upregulated during the proliferation phase of liver regeneration (49).

Our data confirmed miR-205 expression in the basal cell compartment of normal mammary ducts and lobules in the ewe, as already suggested in humans (61) and in mice (1). We further showed that miR-205 was mostly expressed during the first half of pregnancy, with a slight increase already observed at 35 days of pregnancy. This expression was then detected mainly in basal cells surrounding the acini, while miR-21 was strongly expressed in luminal epithelial cells. Interestingly, both miR-21 and miR-205, which are described as targeting the tumour-suppressor phosphatase and tensin homolog (also known as PTEN), were mainly expressed during the first half of pregnancy when proliferation is the most active. Moreover, a recent publication reported that miR-205 is implicated in controlling the differentiation and proliferation of mouse mammary progenitor cells and that its overexpression leads to an expansion of the progenitor cell population (28).

Our microarray data showed that members of the miR-200 family (miR-200a, -200b, -200c, -141, and -429), targeting messengers of the E-cadherin transcriptional repressors ZEB1 (also known as $\delta E F 1$ ) and SIP1 (also known as ZEB2), were all expressed during pregnancy, although with some slight differences; expression increased at the end of pregnancy and lactation. In situ hybridization revealed that expression of the miR-200 family, when detected, was mainly in luminal epithelial cells. Thus, both miR-205 and miR-200 family members were expressed in luminal epithelial cells during the second half of pregnancy. This is the first report of both the temporal and spatial regulation of expression of these miRNA, which may potentiate each other, insofar as miR-205 and members of the miR-200 family have been shown to maintain the epithelial phenotype by inhibiting EMT via the targeting of ZEB1 and ZEB2 transcription factors, two transcriptional repressors of E-cadherin (44).

\section{Conclusions}

This work describes 47 new ovine miRNA and the expression profiles of miRNA during ovine adult mammary gland development. We show for the first time that miR-21 is strongly expressed in epithelial cells of the normal mammary gland at the beginning of pregnancy when proliferation is the most active. This is in line with the overexpression of miR-21 that has been described extensively in many types of cancer, including breast cancer. In addition, miR-205, present during early pregnancy in basal cells and with a peak of expression before midpregnancy, could monitor the stock of progenitor cells by controlling their fate: proliferation and differentiation. Finally, our data showed that miR-205 started to be expressed in epithelial cells during the second half of pregnancy, while miR-200 family members were still present in these cells. As previously described, they may cooperate to maintain epithelial status by repressing an EMT-like program, and to achieve and preserve the secretory phenotype of MEC. These data, taken together with the bidirectional cross talk between mammary parenchyma and mammary fat pad $(20,21,37,55)$ and the epigenetic regulation of the mammary epithelial lineage ( 7 , 50), may provide a foundation for further studies that will unravel mammary gland development.

\section{ACKNOWLEDGMENTS}

The authors thank F. Le Provost for critical reading of the manuscript and J. Laubier for advice with quantitative RT-qPCR experiments. We are grateful to the staff of the IERP Unit (INRA, Jouy-en Josas) for animal care and facilities. Apotome images were performed using the MIMA2 platform facilities, which received financial support from the Ile-de-France region.

\section{GRANTS}

This study received financial support under the 2009 Incentive Grants Programme of the Animal Physiology and Livestock Systems (PHASE) Division of INRA.

\section{DISCLOSURES}

No conflicts of interest, financial or otherwise, are declared by the author(s).

\section{AUTHOR CONTRIBUTIONS}

Author contributions: L.G. and E.D. conception and design of research; L.G., S.D., P.Y., H.B., S.B., and S.T. performed experiments; L.G., S.D., P.Y., and E.D. analyzed data; L.G., S.D., H.B., and E.D. interpreted results of experiments; L.G. and S.D. prepared figures; L.G. drafted manuscript; L.G., S.D., H.B., S.T., and E.D. edited and revised manuscript; L.G., S.D., H.B., S.T., and E.D. approved final version of manuscript.

\section{REFERENCES}

1. Avril-Sassen S, Goldstein LD, Stingl J, Blenkiron C, Le Quesne J, Spiteri I, Karagavriilidou K, Watson CJ, Tavaré S, Miska EA, Caldas C. Characterisation of microRNA expression in post-natal mouse mammary gland development. BMC Genomics 10: 548, 2009.

2. Aydoğdu E, Katchy A, Tsouko E, Lin CY, Haldosén LA, Helguero L, Williams C. MicroRNA-regulated gene networks during mammary cell differentiation are associated with breast cancer. Carcinogenesis 33: 1502-1511, 2012.

3. Barozai MY. The novel 172 sheep (Ovis aries) microRNAs and their targets. Mol Biol Rep 39: 6259-6266, 2012.

4. Bartel DP. MicroRNAs: target recognition and regulatory functions. Cell 136: 215-233, 2009.

5. Bernstein E, Kim SY, Carmell MA, Murchison EP, Alcorn H, Li MZ, Mills AA, Elledge SJ, Anderson KV, Hannon GJ. Dicer is essential for mouse development. Nat Genet 35: 215-217, 2003.

6. Blenkiron C, Goldstein LD, Thorne NP, Spiteri I, Chin SF, Dunning MJ, Barbosa-Morais NL, Teschendorff AE, Green AR, Ellis IO, 
Tavaré S, Caldas C, Miska EA. MicroRNA expression profiling of human breast cancer identifies new markers of tumor subtype. Genome Biol 8: R214, 2007.

7. Bloushtain-Qimron N, Yao J, Snyder EL, Shipitsin M, Campbell LL, Mani SA, Hu M, Chen H, Ustyansky V, Antosiewicz JE, Argani P, Halushka MK, Thomson JA, Pharoah P, Porgador A, Sukumar S, Parsons R, Richardson AL, Stampfer MR, Gelman RS, Nikolskaya T, Nikolsky Y, Polyak K. Cell type-specific DNA methylation patterns in the human breast. Proc Natl Acad Sci USA 105: 14076-14081, 2008.

8. Caiment F, Charlier C, Hadfield T, Cockett N, Georges M, Baurain D. Assessing the effect of the CLPG mutation on the microRNA catalog of skeletal muscle using high-throughput sequencing. Genome Res 20: 1651$1662,2010$.

9. Chakrabarti R, Hwang J, Andres Blanco M, Wei Y, Lukačišin M, Romano RA, Smalley K, Liu S, Yang Q, Ibrahim T, Mercatali L, Amadori D, Haffty BG, Sinha S, Kang Y. Elf5 inhibits the epithelialmesenchymal transition in mammary gland development and breast cancer metastasis by transcriptionally repressing Snail2. Nat Cell Biol 14: 1212$1222,2012$.

10. Chat S, Layani S, Mahaut C, Henry C, Chanat E, Truchet S. Characterisation of the potential SNARE proteins relevant to milk product release by mouse mammary epithelial cells. Eur J Cell Biol 90: 401-413, 2011.

11. Chen CZ, Li L, Lodish HF, Bartel DP. MicroRNAs modulate hematopoietic lineage differentiation. Science 303: 83-86, 2004.

12. Cochrane DR, Cittelly DM, Howe EN, Spoelstra NS, McKinsey EL, LaPara K, Elias A, Yee D, Richer JK. MicroRNAs link estrogen receptor alpha status and Dicer levels in breast cancer. Horm Cancer 1: 306-319, 2010.

13. Cochrane DR, Cittelly DM, Richer JK. Steroid receptors and microRNAs: relationships revealed. Steroids 76: 1-10, 2011.

14. Cochrane DR, Jacobsen BM, Connaghan KD, Howe EN, Bain DL, Richer JK. Progestin regulated miRNAs that mediate progesterone receptor action in breast cancer. Mol Cell Endocrinol 355: 15-24, 2012.

15. Cochrane DR, Spoelstra NS, Richer JK. The role of miRNAs in progesterone action. Mol Cell Endocrinol 357: 50-59, 2012.

16. Colitti M. Expression of keratin 19, Na-K-Cl cotransporter and estrogen receptor alpha in developing mammary glands of ewes. Histol Histopathol 26: 1563-1573, 2011.

17. Colitti M. BCL-2 family of proteins and mammary cellular fate. Anat Histol Embryol 41: 237-247, 2012.

18. Colitti M, Farinacci M. Expression of a putative stem cell marker, Musashi 1, in mammary glands of ewes. J Mol Histol 40: 139-149, 2009.

19. Cui W, Li Q, Feng L, Ding W. MiR-126-3p regulates progesterone receptors and involves development and lactation of mouse mammary gland. Mol Cell Biochem 355: 17-25, 2011.

20. Cunha GR, Hom YK. Role of mesenchymal-epithelial interactions in mammary gland development. J Mamm Gland Biol Neoplas 1: 21-35, 1996.

21. Cunha GR, Young P, Hamamoto S, Guzman R, Nandi S. Developmental response of adult mammary epithelial cells to various fetal and neonatal mesenchymes. Epithel Cell Biol 1: 105-118, 1992.

22. Davis E, Caiment F, Tordoir X, Cavaillé J, Ferguson-Smith A, Cockett N, Georges M, Charlier C. RNAi-mediated allelic trans-interaction at the imprinted Rt11/Peg11 locus. Curr Biol 15: 743-749, 2005.

23. Denamur R. [Nucleic acids of the mammary gland during gestation and lactation in the rabbit]. $C R$ Hebd Seances Acad Sci 256: 4748-4750, 1963.

24. Ellis S, McFadden TB, Akers RM. Prepuberal ovine mammary development is unaffected by ovariectomy. Domest Anim Endocrinol 15: 217-225, 1998.

25. Emane MN, Delouis C, Kelly PA, Djiane J. Evolution of prolactin and placental lactogen receptors in ewes during pregnancy and lactation. Endocrinology 118: 695-700, 1986.

26. Feuermann Y, Robinson GW, Zhu BM, Kang K, Raviv N, Yamaji D, Hennighausen L. The miR-17/92 cluster is targeted by STAT5 but dispensable for mammary development. Genesis 50: 665-671, 2012.

27. Gertler A, Djiane J. Mechanism of ruminant placental lactogen action: molecular and in vivo studies. Mol Genet Metab 75: 189-201, 2002.

28. Greene SB, Gunaratne PH, Hammond SM, Rosen JM. A putative role for microRNA-205 in mammary epithelial cell progenitors. J Cell Sci 123: 606-618, 2010.
29. Gu Z, Eleswarapu S, Jiang H. Identification and characterization of microRNAs from the bovine adipose tissue and mammary gland. FEBS Lett 581: 981-988, 2007.

30. Hata T, Murakami K, Nakatani H, Yamamoto Y, Matsuda T, Aoki N. Isolation of bovine milk-derived microvesicles carrying mRNAs and microRNAs. Biochem Biophys Res Commun 396: 528-533, 2010.

31. He L, Hannon GJ. MicroRNAs: small RNAs with a big role in gene regulation. Nat Rev Genet 5: 522-531, 2004.

32. Hennighausen L, Robinson GW. Information networks in the mammary gland. Nat Rev Mol Cell Biol 6: 715-725, 2005.

33. Hou Q, Huang J, Ju Z, Li Q, Li L, Wang C, Sun T, Wang L, Hou M, Hang S, Zhong J. Identification of splice variants, targeted microRNAs and functional single nucleotide polymorphisms of the BOLA-DQA2 gene in dairy cattle. DNA Cell Biol 31: 739-744, 2012.

34. Hovey RC, Davey HW, Mackenzie DD, McFadden TB. Ontogeny and epithelial-stromal interactions regulate IGF expression in the ovine mammary gland. Mol Cell Endocrinol 136: 139-144, 1998.

35. Hovey RC, McFadden TB, Akers RM. Regulation of mammary gland growth and morphogenesis by the mammary fat pad: a species comparison. J Mamm Gland Biol Neoplas 4: 53-68, 1999.

36. Ibarra I, Erlich Y, Muthuswamy SK, Sachidanandam R, Hannon GJ. A role for microRNAs in maintenance of mouse mammary epithelial progenitor cells. Genes Dev 21: 3238-3243, 2007.

37. Imagawa W, Pedchenko VK, Helber J, Zhang H. Hormone/growth factor interactions mediating epithelial/stromal communication in mammary gland development and carcinogenesis. J Steroid Biochem Mol Biol 80: 213-230, 2002.

38. Iorio MV, Ferracin M, Liu CG, Veronese A, Spizzo R, Sabbioni S, Magri E, Pedriali M, Fabbri M, Campiglio M, Ménard S, Palazzo JP, Rosenberg A, Musiani P, Volinia S, Nenci I, Calin GA, Querzoli P, Negrini M, Croce CM. MicroRNA gene expression deregulation in human breast cancer. Canc Res 65: 7065-7070, 2005.

39. Izumi H, Kosaka N, Shimizu T, Sekine K, Ochiya T, Takase M. Bovine milk contains microRNA and messenger RNA that are stable under degradative conditions. J Dairy Sci 95: 4831-4841, 2012.

40. Ji Z, Wang G, Xie Z, Wang J, Zhang C, Dong F, Chen C. Identification of novel and differentially expressed microRNAs of dairy goat mammary gland tissues using solexa sequencing and bioinformatics. PLoS One 7: e49463, 2012.

41. Ji Z, Wang G, Xie Z, Zhang C, Wang J. Identification and characterization of microRNA in the dairy goat (Capra hircus) mammary gland by Solexa deep-sequencing technology. Mol Biol Rep 39: 9361-9371, 2012.

42. Kann G. Evidence for a mammogenic role of growth hormone in ewes: effects of growth hormone-releasing factor during artificial induction of lactation. J Anim Sci 75: 2541-2549, 1997.

43. Kim YJ, Hwang SJ, Bae YC, Jung JS. miR-21 regulates adipogenic differentiation through the modulation of TGF-beta signaling in mesenchymal stem cells derived from human adipose tissue. Stem Cells 27: 3093-3102, 2009.

44. Korpal M, Lee ES, Hu G, Kang Y. The miR-200 family inhibits epithelial-mesenchymal transition and cancer cell migration by direct targeting of E-cadherin transcriptional repressors ZEB1 and ZEB2. J Biol Chem 283: 14910-14914, 2008.

45. Lagos-Quintana M, Rauhut R, Yalcin A, Meyer J, Lendeckel W, Tuschl T. Identification of tissue-specific microRNAs from mouse. Curr Biol 12: 735-739, 2002.

46. Landgraf P, Rusu M, Sheridan R, Sewer A, Iovino N, Aravin A, Pfeffer S, Rice A, Kamphorst AO, Landthaler M, Lin C, Socci ND, Hermida L, Fulci V, Chiaretti S, Foà R, Schliwka J, Fuchs U, Novosel A, Müller RU, Schermer B, Bissels U, Inman J, Phan Q, Chien M, Weir DB, Choksi R, De Vita G, Frezzetti D, Trompeter HI, Hornung V, Teng G, Hartmann G, Palkovits M, Di Lauro R, Wernet P, Macino G, Rogler CE, Nagle JW, Ju J, Papavasiliou FN, Benzing T, Lichter P, Tam W, Brownstein MJ, Bosio A, Borkhardt A, Russo JJ, Sander C, Zavolan M, Tuschl T. A mammalian microRNA expression atlas based on small RNA library sequencing. Cell 129: 1401-1414, 2007.

47. Le Guillou S, Sdassi N, Laubier J, Passet B, Vilotte M, Castille J, Laloë D, Polyte J, Bouet S, Jaffrézic F, Cribiu EP, Vilotte JL, Le Provost F. Overexpression of miR-30b in the developing mouse mammary gland causes a lactation defect and delays involution. PLoS One 7: e45727, 2012.

48. Li L, Huang J, Ju Z, Li Q, Wang C, Qi C, Zhang Y, Hou Q, Hang S, Zhong J. Multiple promoters and targeted microRNAs direct the expressions of HMGB3 gene transcripts in dairy cattle. Anim Genet 2012. 
49. Marquez RT, Wendlandt E, Galle CS, Keck K, McCaffrey AP. MicroRNA-21 is upregulated during the proliferative phase of liver regeneration, targets Pellino-1, and inhibits NF-kappaB signaling. Am J Physiol Gastrointest Liver Physiol 298: G535-G541, 2010.

50. Maruyama R, Choudhury S, Kowalczyk A, Bessarabova M, Beresford-Smith B, Conway T, Kaspi A, Wu Z, Nikolskaya T, Merino VF, Lo PK, Liu XS, Nikolsky Y, Sukumar S, Haviv I, Polyak K. Epigenetic regulation of cell type-specific expression patterns in the human mammary epithelium. PLoS Genet 7: e1001369, 2011.

51. Matta Reddy A, Zheng Y, Jagadeeswaran G, Macmil SL, Graham WB, Roe BA, Desliva U, Zhang W, Sunkar R. Cloning, characterization and expression analysis of porcine microRNAs. BMC Genomics 10: 65, 2009.

52. Miska EA, Alvarez-Saavedra E, Townsend M, Yoshii A, Sestan N, Rakic P, Constantine-Paton M, Horvitz HR. Microarray analysis of microRNA expression in the developing mammalian brain. Genome Biol 5: R68, 2004.

53. O'Day E, Lal A. MicroRNAs and their target gene networks in breast cancer. Breast Canc Res 12: 201, 2010.

54. Obernosterer G, Martinez J, Alenius M. Locked nucleic acid-based in situ detection of microRNAs in mouse tissue sections. Nat Protoc 2: 1508-1514, 2007.

55. Piantoni P, Bionaz M, Graugnard DE, Daniels KM, Everts RE, Rodriguez-Zas SL, Lewin HA, Hurley HL, Akers M, Loor JJ. Functional and gene network analyses of transcriptional signatures characterizing pre-weaned bovine mammary parenchyma or fat pad uncovered novel inter-tissue signaling networks during development. BMC Genomics 11: 331, 2010 .

56. Pullan S, Wilson J, Metcalfe A, Edwards GM, Goberdhan N, Tilly J, Hickman JA, Dive C, Streuli CH. Requirement of basement membrane for the suppression of programmed cell death in mammary epithelium. $J$ Cell Sci 109: 631-642, 1996.

57. Rowson AR, Daniels KM, Ellis SE, Hovey RC. Growth and development of the mammary glands of livestock: a veritable barnyard of opportunities. Semin Cell Dev Biol 23: 557-566, 2012.

58. Sandra O, Bataillon I, Roux P, Martal J, Charpigny G, Reinaud P, Bolifraud P, Germain G, Al-Gubory KH. Suppressor of cytokine signalling (SOCS) genes are expressed in the endometrium and regulated by conceptus signals during early pregnancy in the ewe. J Mol Endocrinol 34: 637-644, 2005.

59. Sdassi N, Silveri L, Laubier J, Tilly G, Costa J, Layani S, Vilotte JL, Le Provost F. Identification and characterization of new miRNAs cloned from normal mouse mammary gland. BMC Genomics 10: 149, 2009.

60. Selcuklu SD, Donoghue MT, Spillane C. miR-21 as a key regulator of oncogenic processes. Biochem Soc Trans 37: 918-925, 2009.

61. Sempere LF, Christensen M, Silahtaroglu A, Bak M, Heath CV, Schwartz G, Wells W, Kauppinen S, Cole CN. Altered MicroRNA expression confined to specific epithelial cell subpopulations in breast cancer. Cancer Res 67: 11612-11620, 2007.

62. Sheng X, Song X, Yu Y, Niu L, Li S, Li H, Wei C, Liu T, Zhang L, Du L. Characterization of microRNAs from sheep (Ovis aries) using computational and experimental analyses. Mol Biol Rep 38: 3161-3171, 2011.

63. Siegel S, Castellan NJ. Nonparametric Statistics for the Behavioral Sciences. New York: McGraw-Hill, 1988.

64. Smith JJ, Capuco AV, Akers RM. Quantification of progesterone binding in mammary tissue of pregnant ewes. J Dairy Sci 70: 1178-1185, 1987.

65. Smith JJ, Capuco AV, Beal WE, Akers RM. Association of prolactin and insulin receptors with mammogenesis and lobulo-alveolar formation in pregnant ewes. Int J Biochem 21: 73-81, 1989.

66. Sternlicht MD, Kouros-Mehr H, Lu P, Werb Z. Hormonal and local control of mammary branching morphogenesis. Differentiation 74: 365 381, 2006.

67. Sun G, Li H, Rossi JJ. Cloning and Detecting Signature MicroRNAs from Mammalian Cells. Methods Enzymol 427: 123-138, 2007.

68. Sunkar R, Zhu JK. Novel and stress-regulated microRNAs and other small RNAs from Arabidopsis. Plant Cell 16: 2001-2019, 2004.

69. Tesfaye D, Worku D, Rings F, Phatsara C, Tholen E, Schellander K, Hoelker M. Identification and expression profiling of microRNAs during bovine oocyte maturation using heterologous approach. Mol Reprod Dev 76: 665-677, 2009.

70. Turcatel G, Rubin N, El-Hashash A, Warburton D. MIR-99a and MIR-99b modulate TGF- $\beta$ induced epithelial to mesenchymal plasticity in normal murine mammary gland cells. PLoS One 7: e31032, 2012.

71. Ucar A, Vafaizadeh V, Jarry H, Fiedler J, Klemmt PA, Thum T, Groner B, Chowdhury K. miR-212 and miR-132 are required for epithelial stromal interactions necessary for mouse mammary gland development. Nat Genet 42: 1101-1108, 2010.

72. Volinia S, Calin GA, Liu CG, Ambs S, Cimmino A, Petrocca F, Visone R, Iorio M, Roldo C, Ferracin M, Prueitt RL, Yanaihara N, Lanza G, Scarpa A, Vecchione A, Negrini M, Harris CC, Croce CM. A microRNA expression signature of human solid tumors defines cancer gene targets. Proc Natl Acad Sci USA 103: 2257-2261, 2006.

73. Wang M, Moisá S, Khan MJ, Wang J, Bu D, Loor JJ. MicroRNA expression patterns in the bovine mammary gland are affected by stage of lactation. J Dairy Sci 95: 6529-6535, 2012.

74. Watson CJ, Khaled WT. Mammary development in the embryo and adult: a journey of morphogenesis and commitment. Development 135: 995-1003, 2008.

75. Zhao Y, Ransom JF, Li A, Vedantham V, von Drehle M, Muth AN, Tsuchihashi T, McManus MT, Schwartz RJ, Srivastava D. Dysregulation of cardiogenesis, cardiac conduction, and cell cycle in mice lacking miRNA-1-2. Cell 129: 303-317, 2007. 